\title{
VOLATILE ORGANIC COMPOUNDS OF HYBRID RUGOSA ROSES IN LATVIA
}

\author{
Anta Sparinska*\# and Nils Rostoks** \\ * Botanical Garden, University of Latvia, Kandavas iela 2, Rīga, LV-1083, LATVIA; \\ anta.sparinska@lu.Iv \\ ** Faculty of Biology, University of Latvia, Kronvalda bulv 4, Rīga, LV-1586, LATVIA \\ \# Corresponding author
}

Communicated by Dalija Segliṇa

\begin{abstract}
Hybrid Rugosa is the most winter hardy group of roses in the climatic conditions of the Baltic Sea region. This study aimed at identifying new qualities of Hybrid Rugosa by focusing on determination of content of volatile organic compounds of flower petals and in hydrosols produced from these. Volatiles of seven cultivars were extracted using solid phase microextraction (SPME) with subsequent separation by gas chromatography. Identification was made by comparison with mass spectral libraries and by calculating linear retention indexes and comparing them with literature data. Twenty-five volatile aroma compounds were identified in the petals and hydrosols of six Hybrid Rugosa and species. Among those, phenylethylalcohol, B-citronellol, geraniol and nerol were predominant. Species Rosa rugosa and variety 'Plena' showed the highest total level of volatiles and contained $26 \%$ and $31 \%$ B-citronellol, respectively. Varieties 'Raita' and 'Sniedze' contained up to $57 \%$ citronellol. The main volatile compounds were detected in hydrosols in the same proportions, but their concentration was higher than in petals. The varieties 'Raita' and 'Violeta', bred in Latvia, are recommendable for use as a source of hydrosol.
\end{abstract}

Key words: Rosa rugosa, volatile, citronellol, GC/MS, hydrosols.

\section{INTRODUCTION}

Roses are one of the world's most important crops for production of cut flowers, ornamental plants, essential oil and medicinal remedies. The entire diversity of rose cultivars was bred from approximately ten species. One of them is Rosa rugosa from the Far East, used ethnobotanically in health care and oil production in northeastern regions of China. Chinese medicine recommends $R$. rugosa for strengthening blood circulation, for treating stomach aches and dysentery, and also for alleviating liver pains and joint pain (Lee et al., 2008). R. rugosa also has powerful antioxidant, antibacterial and antiinflammatory activity, and inhibits tumour cells and human immunodeficiency virus (HIV) (Fu et al., 2006). Extensive use of the wild $R$. rugosa resulted in excessive decline of its population and it now is a threatened plant in the Red List of China.

When $R$. rugosa species became known in Europe approximately two hundred years ago, it was heralded as the forbear of a new race of garden roses (Nicolas, 1927). Breeders started to cross $R$. rugosa with other species and produce hundreds of hardy cultivars. Hybrid Rugosa is suitable for growing and overwintering in the cold climate of North Europe. Unfortunately, the species spread in the wild, particularly on coastlines and wastelands (Kelager et al., 2012).
Thus, $R$. rugosa is considered as a common invasive species in Europe and North America (Weidema, 2006). This represents a case, when introgression of plant species was not supported with information about its usefulness for improving welfare of people.

The rose breeding programme of the Latvian National Botanic Garden started in the 1960s and resulted in 21 internationally registered Hybrid Rugosa varieties, all suitable for landscapes and hedges, with most of them with good odour and/or edible hips. Our previous research focused on determining ancestry of hybrids using DNA microsatellite markers (Sparinska et al., 2009), and to determine the amounts of $\mathrm{a}$ and $\mathrm{b}$ chlorophylls, carotenoids, and anthocyanins, and free radical 1,1-diphenyl-2-picryl-hydrazil (DPPH) scavenging activity in different parts of the rose plants (Sparinska and Rostoks, 2012). Recently, scientists in Europe have become interested in the content and the potential use in medicine of Hybrid Rugosa petals and hips. Antiradical activity, and content of phenols, anthocyans and proanthocyans have been estimated also in Poland, Finland and Italy (Adamczak et al., 2012; Kylli, 2012; Olech and Nowak, 2012; Patel, 2012). Rose flower fragrance is a composite character that is determined by a complex mixture of low molecular mass volatile molecules, mainly alcohols, esters, aldehydes, ketones, terpenes and alkanes (Hoshidoko, 
1996). Phenylethylalcohol and citronellol are the main constituents of Hybrid Rugosa volatiles with the greatest aromatic intensity. Monoterpene compounds such as citronellol, geraniol, nerol, and their acetate esters are the major headspace compounds of Chinese traditional rose essential oil, and their mass fraction accounts for $50 \%$ to $70 \%$ of the total mass fraction in the essential oil (Feng et al., 2010).

This research focused on determination of the composition and relative abundance of volatile compounds in the headspace of petals and hydrosols of Latvia grown Hybrid Rugosa. In total, six cultivars and the wild growing population was checked to test the hypothesis that Hybrid Rugosa roses in the north of Europe are suitable for use in medicine, cosmetics and health care, similarly as in China.

\section{MATERIALS AND METHODS}

Plant material. The rose cultivars used in the present study are a part of the breeding programme and collection of the Latvian National Botanic Garden. For detection of volatile oils a wild population of $R$. rugosa (coordinates: N 56.945733 , E 24.28246) covering a total area of $200 \mathrm{~m}^{2}$ and six Hybrid Rugosa cultivars were used: three of bred by Latvian scientist Dr. agr. Dzidra Rieksta and internationally registered ('Raita', 'Sniedze', 'Violeta') and the others were their parental varieties 'Plena', 'Frau Dagmar Hastrup' and 'Schneezwerg'. Morphological characteristics of the $R$. rugosa and Hybrid Rugosa are provided in Table 1. All plants were mature, seven years old, healthy and abundantly blooming. Cultivars were grown under similar conditions in heavy loam soil without external irrigation. The flowers were collected randomly from groups of ten plants for each sample.

At the end of June 2012, half to full open flowers were harvested about 8:00 in the morning on sunny days in three biological replicates, packed in labelled plastic bags and immediately transported to the laboratory for testing.

Preparation of hydrosol. Hydrosols of fresh rose petals (35 g per sample) were obtained during $2 \mathrm{~h}$ in a hydrodistillation apparatus with $350 \mathrm{~mL}$ water (1 : 10; w/v). Hydrosols were kept in dark under refrigerated conditions, temperature $+4{ }^{\circ} \mathrm{C}$ until use. Approximately $175 \mathrm{~mL}$ hydrosol was obtained by hydrodistillation of each batch.

\section{Detection and identification of volatile aroma com-} pounds. The volatile aroma compounds in rose petals and hydrosol were determined by means of headspace solid-phase microextraction (SPME) followed by gas chromatography-mass spectrometry (GC-MS) analysis.

Volatiles from roses were extracted using solid phase microextraction (SPME). $0.5 \mathrm{~g}$ of rose petals and $5 \mathrm{~g}$ of hydrosol were weighed in a $20 \mathrm{ml}$ head-space vial and capped with a septum. For SPME extraction, divinylbenzene/Carboxen/polydimethylsiloxane (DVB/Car/ PDMS) fibre (Supelco Inc., Bellefonte, PA, USA) was used. SPME parameters were: incubation time $10 \mathrm{~min}$, extraction temperature $35 \pm 1{ }^{\circ} \mathrm{C}$, duration of extraction $30 \mathrm{~min}$, desorption $15 \mathrm{~min}, 250{ }^{\circ} \mathrm{C}$. For the analysis of the SPME extracts, a Perkin Elmer Clarus 500 GC/MS and an Elite-Wax ETR column $(60 \mathrm{~m} \times 0.25 \mathrm{~mm}$ i.d.; DF $0.25 \mu \mathrm{m})$ were used. Working conditions were: injector $250{ }^{\circ} \mathrm{C}$; transfer line to MSD $260{ }^{\circ} \mathrm{C}$; oven temperature from $40{ }^{\circ} \mathrm{C}$, hold $10 \mathrm{~min}$, programmed from 40 to $60{ }^{\circ} \mathrm{C}$ at $2{ }^{\circ} \mathrm{C} \mathrm{min}{ }^{-1}$, and from 60 to $250{ }^{\circ} \mathrm{C}$ at $20{ }^{\circ} \mathrm{C} / \mathrm{min}$, hold $5 \mathrm{~min}$; carrier gas (He) $1 \mathrm{~mL} \mathrm{~min}^{-1}$; split ratio $2: 1$; ionisation $\mathrm{EI}+$ mode; acquisition parameters in full scan mode: scanned m/z 40-400. Tentatively identified compounds were determined by comparing their mass spectra with mass spectral libraries (Nist98 and Wiley 6th) and by calculating linear retention indexes and comparing them with literature data. As a quantitative measure, the share in the total GC peak area for each compound was estimated. The percentage compositions of the samples were computed from the GC peak areas.

Analysis of variance (ANOVA) and correlation analysis was performed by Microsoft Excel Analyse-it Standard Edition package. Probability $p<0.05$ was considered as statistically significant.

\section{RESULTS}

The highest level of total volatile aroma compounds in comparison to those of other rose varieties used in the study was found in the head-space of $R$. rugosa 'Plena'. The low-

Table 1

MORPHOLOGICAL CHARACTERISTICS OF THE RUGOSA HYBRIDS

\begin{tabular}{|c|c|c|c|c|c|c|c|c|}
\hline \multirow[t]{2}{*}{ Variety } & \multicolumn{2}{|l|}{ Plant } & \multicolumn{3}{|c|}{ Foliage } & \multicolumn{3}{|c|}{ Flowers } \\
\hline & Habitus & High (m) & $\begin{array}{c}\text { Intensity of } \\
\text { green }\end{array}$ & Size & Diameter & Type & Colour & Fragrance \\
\hline R. rugosa (wild population) & moderatly spreading & 1.5 & dark & medium & medium & single & pink & strong \\
\hline Frau Dagmar Hastrup & intermediate & 2.0 & medium & medium & large & single & pink blend & strong \\
\hline Raita & upright & 1.7 & light & medium & medium & semi double & pink & medium \\
\hline Schneezwerg & moderatly spreading & 1.0 & dark & small & small & semi double & white & weak \\
\hline Sniedze & upright & 2.0 & medium & medium & medium & double & pure white & heavy \\
\hline Violeta & upright & 1.6 & dark & medium & large & double & red purple & medium \\
\hline Plena & moderately spreading & 1.5 & dark & medium & medium & semi double & pink & strong \\
\hline
\end{tabular}


est level of volatile compounds was found in head-space of 'Schneezwerg'. Variety 'Raita' contained the widest diversity of volatile compounds. 'Sniedze' contained up to $57 \%$ of citronellol, but had lower concentrations of other compounds. Variety 'Violeta' contained $37 \%$ of citronellol, $15 \%$ of geraniol and $31 \%$ nerol.

Twenty-five volatile compounds were detected in petals and hydrosols of Hybrid Rugosa (Fig. 1). The volatiles found in the largest amounts were phenylethylalcohol $(28.6 \pm 2.6 \%$ $-79.9 \pm 3.1 \%$ depending on variety), citronellol (28 \pm $1.5-57 \pm 4.8 \%$ depending on variety) and nerol (up to $39 \pm$ $0.9 \%$ of the total amount of volatiles). The relative concentrations of these in different rose varieties is shown in Figure 1.

Comparing the total peak area of volatile compounds in flower petals and hydrosol, the concentration of total volatiles was highest in the hydrosols, except in cultivar 'Frau Dagmar Hastrup'. Apparently, the process of preparing the rose water released associated volatile compounds from the petals. For example, trans-rose oxide and linalool were not detected in rose petals.
The differences between total concentrations of volatile compounds among cultivars were significant $(p<0.05)$. About $89-96 \%$ of the total concentration of volatiles in rose petals is composed of alcohols, depending on variety. In addition, a strong correlation $r^{2}=0.87$ was found between amount of alcohols and other volatiles in headspace and hydrosols. In the hydrosols, relative concentration of alcohols among volatile compounds in petals of cultivars decreased to $70-80 \%$, while the concentration in R. rugosa was $90.3 \%$ of total peak area.

\section{DISCUSSION}

Almost all plants are able to emit volatile compounds and the content and composition of these organic compounds shows both genotypic variation and phenotypic plasticity (Dudareva and Pichersky, 2000). Rose flower volatiles are considered important for human use, especially those obtained from $R$. damascena grown in valleys of Bulgaria. Recent investigation showed that $R$. damascena grown in North India can produce a composition of volatiles equivalent to international standards for rose oil (Verma et al., 2011). Besides industrial cultivation of $R$. damascena, dur-

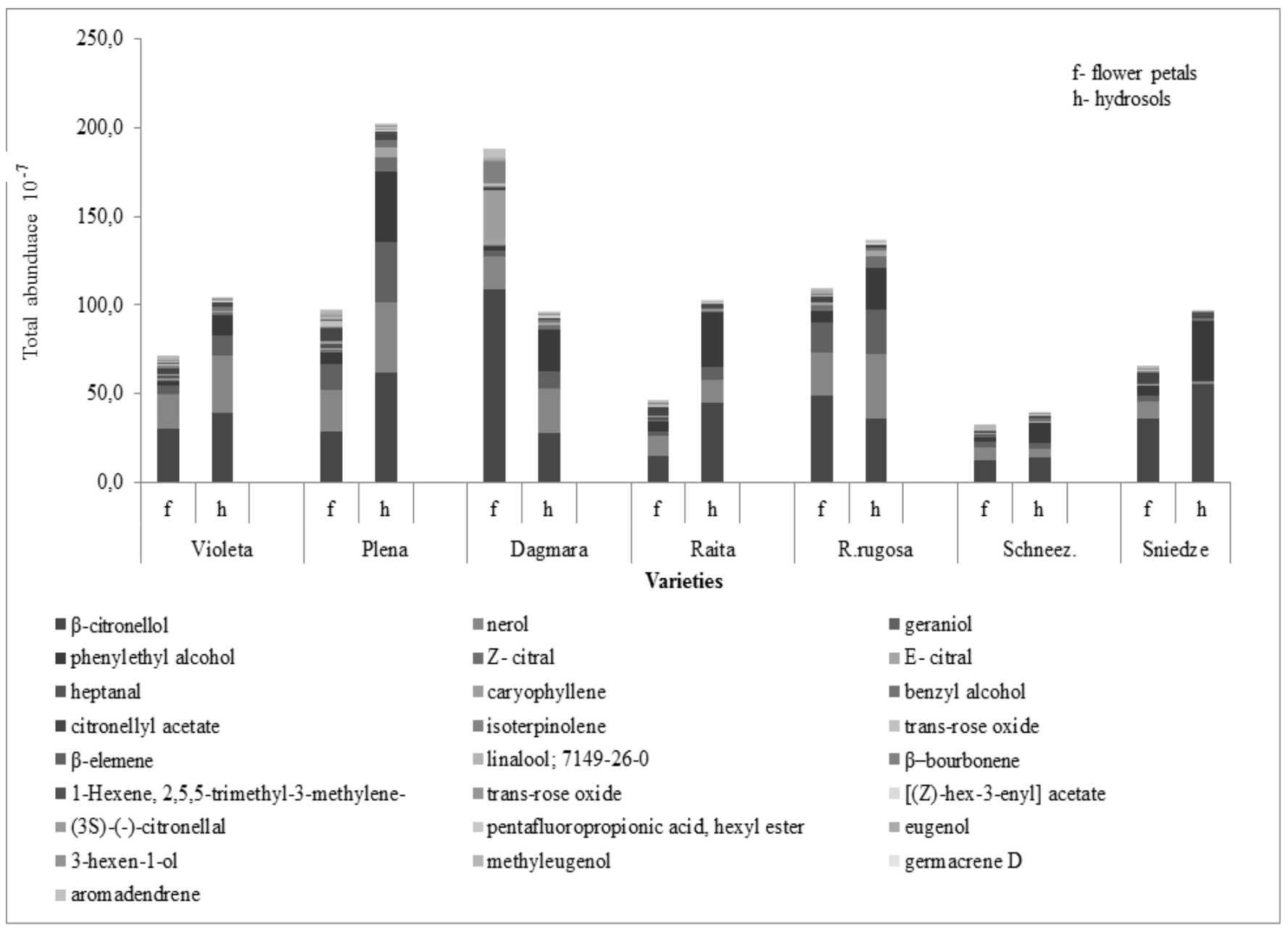

Fig. 1. Total peak area $\left(\times 10^{-7}\right)$ of volatile compounds in headspace of varieties of Hybrid Rugosa rose petals and hydrosol detected with headspace solid-phase microextraction (SPME) followed by gas chromatography-mass spectrometry (GC-MS) analysis. The values represent the relative proportion of the total peak area (averages of three replicates from 2012 season) (f - flower petals, h - hydrosol). 
ing the last century plantations of other roses have been established as well, e.g., $R$. gallica, $R$. francofurtana, $R$. centifolia and $R$. rugosa (Kovacheva et al., 2010). A recent study from China reported that $R$. rugosa petals contained 33 volatile compounds in 23 accessions (Feng et al., 2010).

In this study, 25 volatile compounds were detected from seven varieties of roses. The most abundant alcohol compounds were phenylethylalcohol, citronellol, nerol, and cis-geraniol, which have been reported as the major components in fresh flowers of Chinese R. rugosa (Feng et al., 2010). The volatiles found in the largest amounts in Latvian Hybrid Rugosa were phenylethylalcohol (up to 79.9\%), citronellol (up to 57\%) and nerol (up to $39 \%$ ).

The floral scent of Iranian Rosa damascena flowers contains $47 \%$ of the $\beta$-citronellol (Karami et al., 2013). Concentration of citronellol in variety 'Raita' (43\% in fully opened flowers) was similar to that of $R$. damascene, while introduced varieties 'Plena' and 'Frau Dagmar Hastrup' contained even higher concentrations reaching up to $57 \%$ of this main component of rose oil.

Due to its good solubility in water, phenylethylalcohol passes almost completely into the aqueous phase during steam distillation, but is completely lost in process of preparing rose oil. Consequently, rose water contains a high quantity of phenylethylalcohol. A volatile concentrate obtained from rose water ( $R$. damascena flowers) was found to consist mainly of phenylethylalcohol (69.7-81.6\%), linalool (1.5-3.3\%), citronellol (1.8-7.2\%), nerol $(0.2-4.2 \%)$, geraniol $(0.9-7.0 \%)$ along with rose oxides and all other characteristic minor rose compounds (Agarwall et al., 2005). In our study, lower concentration of phenylethylalcohol was observed in rose water, with only varieties 'Raita' and 'Sniedze' containing 30-35\% henylethylalcohol.

International standards of rose oil obtained from $R$. damascena (ISO9842:2003) specify certain characteristics of oil of $R$. damascena cultivated in Turkey, Morocco, and Bulgaria. These standards require that the oil must contain $20-49 \%$ of citronellol, $15-20 \%$ of geraniol and up to $30 \%$ of nerol. Volatile compound content in petals of 'Violeta' were very close to these standards. The use of $R$. rugosa and its hybrids grown in North of Europe for oil extraction was unclear until now. The current study suggests that chemical composition of the Latvian grown $R$. rugosa and Hybrid Rugosa volatiles makes them promising as a source of hydrosol, because content and ratio of main volatile compounds are similar to that of R. rugosa used for rose oil in China, and the main components and their concentrations approach $R$. damascene standards Based on the observed concentrations of volative compounds in Latvian Hybrid Rugosa varieties and considering that variation in composition of minor compounds does not affect the antioxidative and cytotoxic activity of the end products (Bakkali et al., 2008), the Latvian rose varieties and other locally grown Hybrid Rugosa are suitable for potential use as source of rose water, due to the high content of volatiles and diversity of compounds.

\section{ACKNOWLEDGEMENTS}

The study was partly funded by the European Social Fund within the project "Support for Doctoral Studies at University of Latvia - 2”, contract 2011/0054/1DP/ 1.1.2.1.2/11/ IPIA/VIAA/002. Latvia University of Agriculture, National Botanic Garden, and personally Dr. agr. Dzidra Rieksta are gratefully acknowledged.

\section{REFERENCES}

Adamczak, A., Buchwald, W., Zieliński, J., Mielcarek, S. (2012). Flavonoid and organic acid content in rose hips. (Rosa L., Sect. Caninae Dc. Em. Christ.). Acta Biol. Cracoviensia Bot., 54, 105-112.

Agarwal, S. G., Gupta, A., Kapahi, B. K., Baleshwar, Thappa, R. K., Suri, O. P. (2005). Chemical composition of rose water volatiles. J. Essent. Oil Res., 17, 265-267.

Bakkali, F., Averbeck, S., Averbeck, D., Idaomar, M. (2008). Biological effects of essential oils: A review. Food Chem. Toxicol., 46 (2), 446-475.

Boskabady, M. H., Shafei, M. N., Saberi, Z., Amini, S. (2011). Pharmacological effects of Rosa damascena. Iran. J. Basic Med. Sci., 14, 295-307.

Dudareva, N., Pichersky, E. (2000). Biochemical and molecular genetic aspects of floral scents. Plant Physiol., 122, 627-633.

Feng, L.-G., Chen, C., Sheng, L.-X., Liu, P., Tao, J., Su, J.-L., Zhao, L.-Y. (2010). Comparative analysis of headspace volatiles of Chinese Rosa rugosa. Molecules, 15, 8390-8399.

Fu, L. K., Chin, C. M. (eds.) (1992). China Plant Red Data Book: Rare and Endangered Plants. Marrickville: Science Press. 741 pp.

Fu, M., Ng, T. B., Jiang, Y., Pi, Z. F., Liu, Z. K., Li, L., Liu, F. (2006). Compounds from rose (Rosa rugosa) flowers with human immunodeficiency virus type 1 reverse transcriptase inhibitory activity. J. Pharm. Pharmacol., 58, 1275-1280.

Hashidoko, Y., Endoh, K., Kudo, T., Tahara, S. (2001). Capability of wild Rosa rugosa and its varieties and hybrids to produce sesquiterpene components in leaf glandular trichomes. Biosci Biotechnol Biochem., 65, 2037-2043.

Karami, A., Khosh-Khui, M., Salehi, H., Saharkiz, J. M., Rowshan, V. (2013). Headspace analysis of floral scent from two distinct genotypes of Iranian Damask Rose (Rosa damascena Mill.). J. Essent. Oil Bearing, 16, 489-498.

Kelager, A., Pedersen, J. S., Bruun, H. H. (2012). Multiple introductions and no loss of genetic diversity: Invasion history of Japanese Rose, Rosa rugosa, in Europe. Biol. Invasions, 15, 1125-1141.

Kovacheva, N., Rusanov, K., Atanassov, I. (2010). Industrial cultivation of oil bearing rose and rose oil production in Bulgaria during $21^{\text {st }}$ century, directions and challenges. Biotechnol. Biotechnol. Equip. J., 24, 1793-1798.

Kylli, P. (2011). Berry phenolics: Isolation, analysis, identification, and antioxidant properties. Doctoral dissertation, University of Helsinki, Finland.

Kumar, N., Bhandari, P., Singh, B., Bari, S. S. (2009). Antioxidant activity and ultra-performance LC-electrospray ionization-quadrupole time-offlight mass spectrometry for phenolics-based fingerprinting of Rose species: Rosa damascena, Rosa bourboniana and Rosa brunonii. Food Chem. Toxicol., 47, 361-367.

Lee, Y. H., Jung, M. G., Kang, H. B., Choi, K. C., Haam, S, Jun, W., Kim, Y. J, Cho, H. Y., Yoon, H. G. (2008). Effect of anti-histone acetyltransferase activity from Rosa rugosa Thunb. (Rosaceae) extracts on androgen receptor-mediated transcriptional regulation. J. Ethnopharmacol., 118, $412-417$.

Mikanagi, Y., Saito, N., Yokoi, M., \& Tatsuzawa, F. (2000). Anthocyanins in flowers of genus Rosa, sections Cinnamomeae (=Rosa), Chinenses, Gallicanae and some modern garden roses. Biochem. Syst. Ecol., 28, 887-902. 
Nicolas, J. H. (1927). Sterility encountered in rose breeding. Mem. Hort. Soc., 3, 55-57.

Olech, M., Nowak, R. M. (2012). Influence of different extraction procedures on the antiradical activity and phenolic profile of Rosa rugosa petals. Acta Pol. Pharm., 69, 501-507.

Patel, S. (2013). Rose hips as complementary and alternative medicine: Overview of the present status and prospects. Mediterr. J. Nutr. Metab., 6, 89-97.

Shalit, M., Guterman, I., Volpin, H., Bar, E., Tamari, T., Menda, N., Adam, Z., Zamir, D., Vainstein, A., Weiss, D., Pichersky, E., Lewinsohn, E. (2003). Volatile ester formation in roses. Identification of an acetyl-

Received 30 September 2014 coenzyme A. Geraniol/Citronellol acetyltransferase in developing rose petals. Plant Physiol., 131, 1868-1876.

Sparinska, A., Rostoks, N. (2012). Comparing ornamental and other quality traits of Rosa rugosa hybrids in Latvia. Acta Hort., 953, 277-283.

Sparinska, A., Zarina, R., Rostoks, N. (2009). Diversity in Rosa rugosa $\mathrm{x}$ Rosa x hybrida interspecific cultivars. Acta Hort., 836, 111-116.

Verma, S., Padalia, R.C., Chauhan, A., Singh, A., Yadav, A. K. (2011). Volatile constituents of essential oil and rose water of damask rose (Rosa damascena Mill.) cultivars from North Indian hills. Nat. Prod. Res., 25, 1577-1584.

Weidema, I. (2006). NOBANIS - Invasive Alien Species Fact Sheet - Rosa rugosa. Available at Online Database of the European Network on Invasive Alien Species - NOBANIS. www.nobanis.org (accessed 10 December 2008).

\section{GAISTOŠIE SAVIENOJUMI RUGOSAS HIBRĪDU ROŽU ZIEDLAPĀS UN HIDROSOLĀ}

Rugosas hibrīdi ir viena no visizturīgākajām dārza rožu grupām Baltijas jūras klimatā. Šī pētījuma mērḳis ir identificēt jaunas, Latvijā neizmantotas, Rugosas hibrīdu ziedu kvalitātes, pārbaudot šķirṇu piemērotību rožu hidrozola jeb rožūdens ieguvei. Septiṇu škiniṇu gaistošo savienojumu ekstrakciju veica ar cietās fāzes mikroekstrakciju un tai sekojošu gāzes hromatogrāfiju, iegūtos savienojumus identificēja, izmantojot masu spektru bibliotēku Nist98. Rožu ziedlapās un hidrozolos konstatēja 25 gaistošos savienojumus. Visu šķirņu un Rosa rugosa gaistošie savienojumos izdalīja feniletilspirtu, citronelolu, geraniolu un nerolu. Visaugstākais savienojumu daudzums bija $R$. rugosa un 'Plena', attiecīgi $26 \%$ un $31 \%$ citronelola. No hidrosola tika izdalīti savienojumi līdzīgās proporcijās, bet divreiz lielākā daudzumā, nekā ziedlapās. No Latvijā selekcionētajām šķirnēm, kā rožūdens avots būtu iesakāmas šķirnes 'Raita' un 'Violeta'. 